\title{
Diet and breeding performance of black-legged kittiwakes Rissa tridactyla at a North Sea colony
}

\author{
S. Lewis ${ }^{1, *}$, S. Wanless ${ }^{1, * *}$, P. J. Wright ${ }^{2}$, M. P. Harris ${ }^{1}$, J. Bull ${ }^{1}$, D. A. Elston ${ }^{3}$ \\ ${ }^{1}$ CEH Centre for Ecology and Hydrology, Banchory Research Station, Hill of Brathens, Kincardineshire AB31 4BW, \\ United Kingdom \\ ${ }^{2}$ FRS Marine Laboratory, PO Box 101, Victoria Road, Aberdeen AB11 9DB, United Kingdom \\ ${ }^{3}$ BioSS, Environmental Modelling Unit, Macaulay Land Use Research Institute, Craigiebuckler, Aberdeen AB15 8QH, \\ United Kingdom
}

\begin{abstract}
The lesser sandeel Ammodytes marinus is a key prey species for many avian predators in the North Sea, and is the target of the largest single species fishery in the area. This has led to concern about the potential impact of the fishery on seabirds. The most vulnerable predatory species are small and surface-feeding, characteristics that are exemplified by the black-legged kittiwake Rissa tridactyla. This paper reports on the first assessment of seasonal changes in prey composition and prey size for the kittiwake in the North Sea during 4 breeding seasons (1997 to 2000) in which breeding success varied dramatically. Kittiwake diet showed little inter-annual variation, with a welldefined seasonal change from planktonic crustacea in early spring, to 1+ group sandeels in April and May, to 0 group sandeels in June and July. However, there was evidence that temporal differences in sandeel life history events were well reflected in both kittiwake diet and breeding success. Thus, the most successful year (2000) was characterised by the earliest appearance of 0 group sandeels, while the least successful season had the latest appearance. There was also a link between annual variations in breeding success and sandeel size such that success was lower when 0 group sandeels were smaller and hence of lower energy value. Our study included 3 seasons $(1997,1998,1999)$ during which the industrial fishery was operating within $50 \mathrm{~km}$ of the study colony and 1 (2000) in which the fishing grounds were closed. The higher breeding success in 2000 than in the other years suggests that the closure of the fishery might have had an immediate and positive effect on kittiwake productivity. However, as the dietary data indicated, the earlier appearance and rapid growth rates of 0 group sandeels in 2000 suggests that the enhanced breeding success was more likely to have been a response to environmental factors influencing the growth and timing of life history transitions of this prey.
\end{abstract}

KEY WORDS: Ammodytes marinus · Industrial fisheries · Seabird · Predator-prey interactions · Sandeel $\cdot$ Reproductive success

\section{INTRODUCTION}

The lesser sandeel Ammodytes marinus is an extremely abundant, lipid-rich fish that is a key prey species for many North Sea seabirds during their breeding seasons (Monaghan et al. 1989, Furness

\footnotetext{
*Present address: Department of Biological Sciences, University of Durham, South Road, Durham DH1 3LE, United Kingdom

**Corresponding author. E-mail: swanl@ceh.ac.uk
}

1990, Harris \& Wanless 1990, 1991, Bailey 1991, Hamer et al. 1991, 1992). It is also the target of the largest single species fishery in the North Sea with annual catches of between 0.7 and 1.1 million $t$ over the last $10 \mathrm{yr}$ (Gislason \& Kirkegaard 1998, ICES 2001). The size of this industrial fishery, coupled with the importance of sandeels to marine predators, has led to concern over the potential impact of sandeel harvesting on the North Sea ecosystem and speculation that the fishery and birds might be competing for the same resource (Monaghan 1992). 
The degree to which seabird species are affected by changes in sandeel availability varies, the most potentially vulnerable being small, surface-feeding species with high foraging costs and a high risk of predation of unattended clutches or broods (Furness \& Tasker 2000). The black-legged kittiwake Rissa tridactyla falls into this high risk category. To date, most studies have indicated that kittiwakes in the North Sea take mainly 0 group sandeels (fish hatched in the current year) during the breeding season (Heubeck \& Ellis 1986, Harris \& Riddiford 1989, Harris \& Wanless 1990, 1997, Wright \& Bailey 1993). Thus it is likely that variation in sandeel recruitment would have an immediate (i.e., same season) effect on the species' breeding success. Size variation (and hence calorific density, which increases with body length; Hislop et al. 1991) tends to be greater in 0 group sandeels than among older age classes (Cameron 1958, Wright 1996, Wright \& Bailey 1996) so that the range in quality of prey taken by kittiwakes is also likely to be variable. Consistent with these suggestions are the positive correlations between kittiwake breeding success and the proportion of 0 group sandeels in the diet during the chick rearing period and the size of these fish (Harris \& Wanless 1990, 1997, Monaghan 1996). However, kittiwake breeding success has also been shown to correlate with the availability, or abundance, of 1+ group sandeels in the North Sea (Wanless \& Harris 1992, Furness 1999a,b, Rindorf et al. 2000), suggesting that kittiwake reproductive output can also be affected by older age classes of their prey.

We carried out an intensive investigation of kittiwake diet at a colony in the northwestern North Sea during 4 breeding seasons. There were 2 main objectives: (1) to provide the first detailed assessment of intra- and interannual changes in prey composition and prey size in this region; and (2) to examine whether variations in kittiwake breeding success could be linked to diet. Our study colony was situated approximately $50 \mathrm{~km}$ from important sandeel fishing grounds on the Wee Bankie, Marr Bank and Scalp Bank. These grounds were first fished in 1990; catches reached a peak of $115000 \mathrm{t}$ in 1993 but subsequently declined to $22000 \mathrm{t}$ in 1999 (ICES 2000). In 2000 the fishery was closed in response to concerns about breeding failures of kittiwakes at nearby colonies (ICES 2000). Thus our study period included 3 seasons (1997, 1998 and 1999) during which the industrial fishery was operating and 1 (2000) in which it was closed.

\section{METHODS}

Diet sampling. Data were collected at the breeding colony of 4000 to 7000 pairs of kittiwakes on the Isle of May $\left(56^{\circ} 11^{\prime} \mathrm{N}, 02^{\circ} 33^{\prime} \mathrm{W}\right)$, Firth of Forth, southeast
Scotland, between 25 March and 17 July 1997, 24 March and 19 July 1998, 26 March and 18 July 1999, and 30 March and 26 July 2000.

Adult birds were caught on nests using a nylon noose attached to the end of an $8 \mathrm{~m}$ telescopic pole. During routine handling associated with ringing and weighing birds, some birds regurgitated. All bird handlers used a standard method of capturing and handling birds, and were all trained by the same person, to reduce any bias among handlers. Each regurgitate was weighed to $\pm 0.1 \mathrm{~g}$ using a digital balance, and an immediate qualitative assessment was made of the species composition and approximate size of individual items. Most prey items were too digested to allow accurate measurements of body length and estimates of prey size were derived indirectly from sagittal otoliths. Each regurgitate was placed in a saturated solution of biological washing powder (Biotex) and kept in an oven at 40 to $50^{\circ} \mathrm{C}$ for at least $5 \mathrm{~h}$ until flesh and soft material had been digested. All the remaining otoliths and fish bones were identified using a binocular microscope (25× magnification) and keys in Härkönen (1986) and Watt et al. (1997). Each sandeel sagittal otolith was measured along the maximum otolith diameter (MOD) to within $\pm 27 \mu \mathrm{m}$ using a calibrated eyepiece graticule. The age class (0 group, 1 group, 2 group, etc.) of each otolith (and hence of the fish from which it originated) was determined from otolith macrostructure using counts of annuli (ICES 1995).

To back-calculate the lengths of sandeels taken by kittiwakes from the otolith diameters, we collected intact sandeels by mist-netting Atlantic puffins, Fratercula arctica, carrying food to their chicks on the Isle of May. Puffins take a similar size range of fish to kittiwakes. Fresh sandeels were sorted into $5 \mathrm{~mm}$ total length (TL) classes $(\mathrm{TL}=$ snout to tip of tail; range 35 to $170 \mathrm{~mm}$ ). Twenty fish of most length classes were stored deepfrozen until later examination. For each length class of fish, otoliths were extracted and measured using the method described above, and the data were used to determine year- and age-specific ( 0 group, and 1 group and older) relationships between TL and MOD (Appendix 1). These equations were then used to back-calculate the lengths of sandeels in the kittiwake food samples.

To compare annual relationships between TL and date for 0 group and 1 group sandeels, respectively, we computed independent regressions for each variable and year. We used a linear model for TL against MOD and a quadratic model for MOD against Julian date. We obtained estimates of mean predicted sandeel lengths for a given day in any year by substitution, and corresponding variances by standard formulae for sums and products. We tested for differences among the 4 years on selected dates, by referencing Wald statistics to $\chi_{3}^{2}$ distributions. 
Breeding success. Data on overall reproductive success (chicks fledged in each active nest) were collected using standardised methods (Harris \& Wanless 1990) in 15 plots dispersed through the colony to provide a representative sample of the main habitats. A further 100 to 200 nests were followed in detail each year to provide more precise information on when nests failed.

\section{RESULTS}

\section{Regurgitations}

The mean mass of loads regurgitated by kittiwakes did not vary among years (ANOVA: $F_{3,650}=1.62, \mathrm{p}=$ 0.18 ) but the probability of a bird regurgitating during handling did differ $\left(\chi^{2}{ }_{3}=12.9, \mathrm{p}<0.005\right)$, being consistently higher in $2000(30.6 \%, \mathrm{n}=522)$ than in the other 3 years (1997: $25.2 \%, \mathrm{n}=448 ; 1998: 22.0 \%, \mathrm{n}=859$; 1999: $24.8 \%, n=675$ ). Inspection of the within-season patterns indicated that this difference was due mainly to a sharp decrease in the frequency of regurgitation in early June in 1997, 1998 and 1999 (Fig. 1).

\section{Diet}

Sandeels were the main prey item taken by kittiwakes on the Isle of May in all 4 breeding seasons
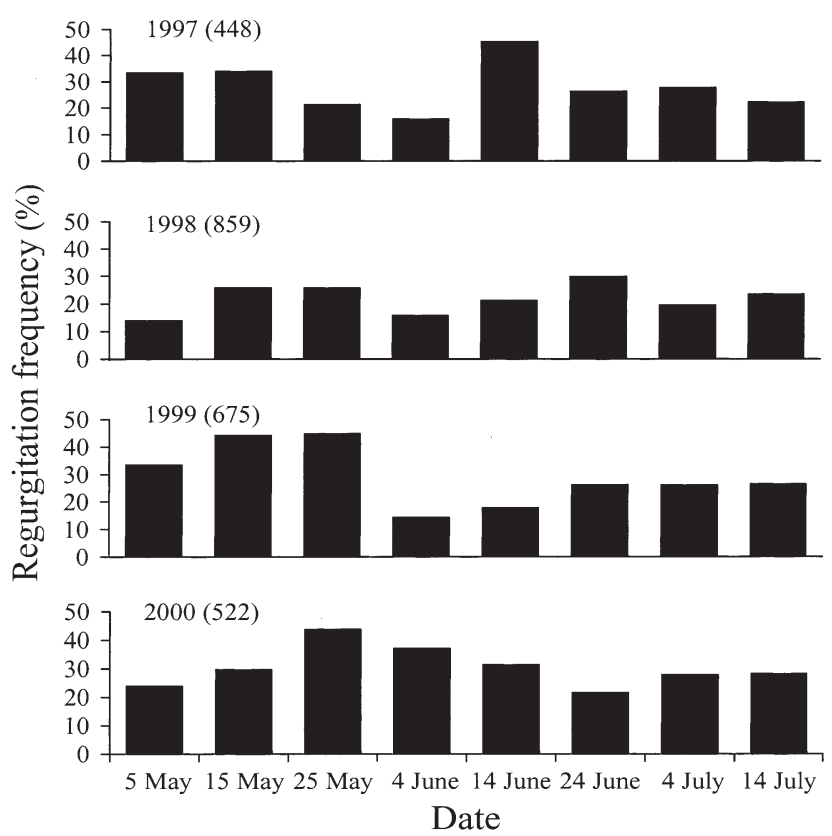

Fig. 1. Seasonal variation in the frequency with which blacklegged kittiwakes on the Isle of May regurgitated in 1997, 1998, 1999 and 2000. The number of birds sampled each year is given in brackets
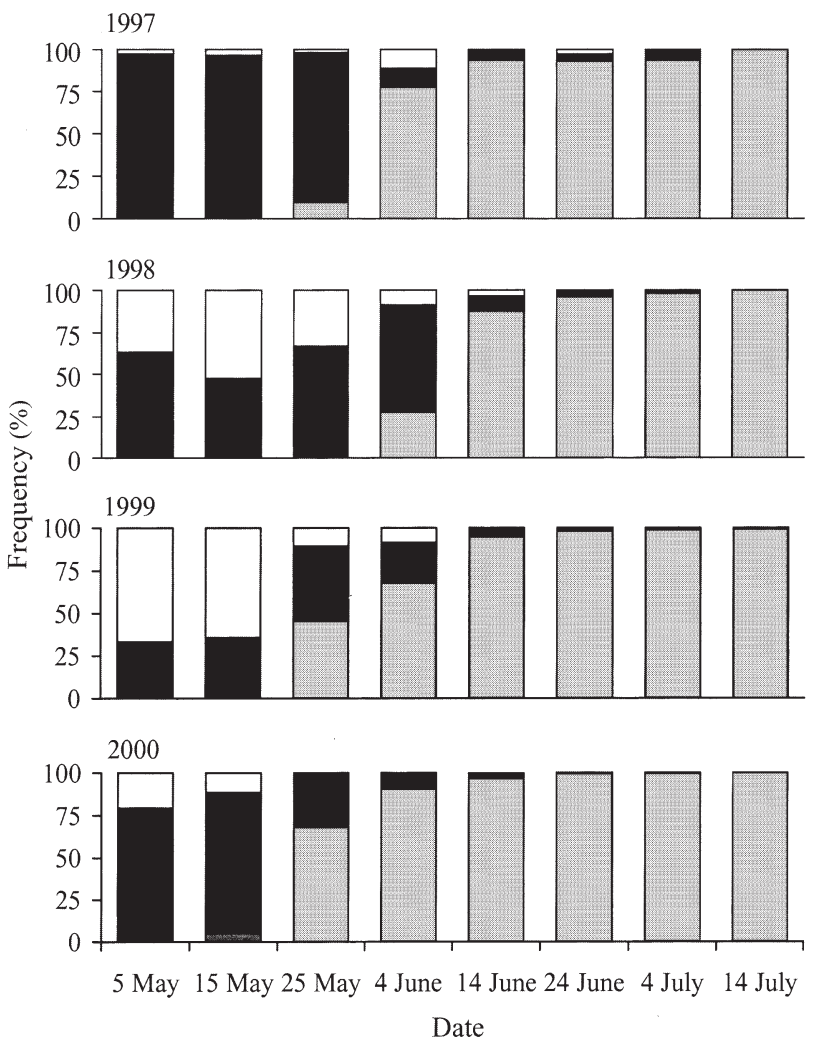

Fig. 2. Seasonal variation in the percentage of 0 group ( $\square$ ), 1 group ( $\square$ ) and older ( $\boldsymbol{\square})$ sandeels taken by black-legged kittiwakes on the Isle of May in 1997, 1998, 1999 and 2000

(Table 1). However, in every year, planktonic crustacea, mainly Thysanoessa inermia, were important early in the season while clupeids (almost entirely sprats Sprattus sprattus) showed a small, but consistent, increase in frequency of occurrence in the middle of the sampling period.

Table 1 also illustrates the marked seasonal shift in the predominant age class of sandeel in the diet; this trend is shown in more detail in Fig. 2. The most pronounced effect was that during the early part of the season, all the sandeels taken were at least $1 \mathrm{yr}$ old, while in the latter part, 0 group was the dominant age class, accounting for $>90 \%$ of the sandeels recorded. The timing of the first appearance of 0 group sandeels in the diet varied among years, being earliest in 2000 (17 May), followed by 1999 (21 May), 1997 (29 May) and 1998 (2 June). In each year the changeover from $>50 \% 1+$ group to $>50 \% 0$ group took approximately $20 \mathrm{~d}$ (Fig. 2). It was also apparent that the age classes of sandeels taken by kittiwakes during the first 2 sampling periods in May varied among years, with 1 group dominating in 1997 and 2000 (ratios of 1 group:2+ group of 19:1 and 8:1, respectively), 1 group and 2+ group equally represented in 1998 (1:1) and 2+ group dominating in 1999 (1:2). 


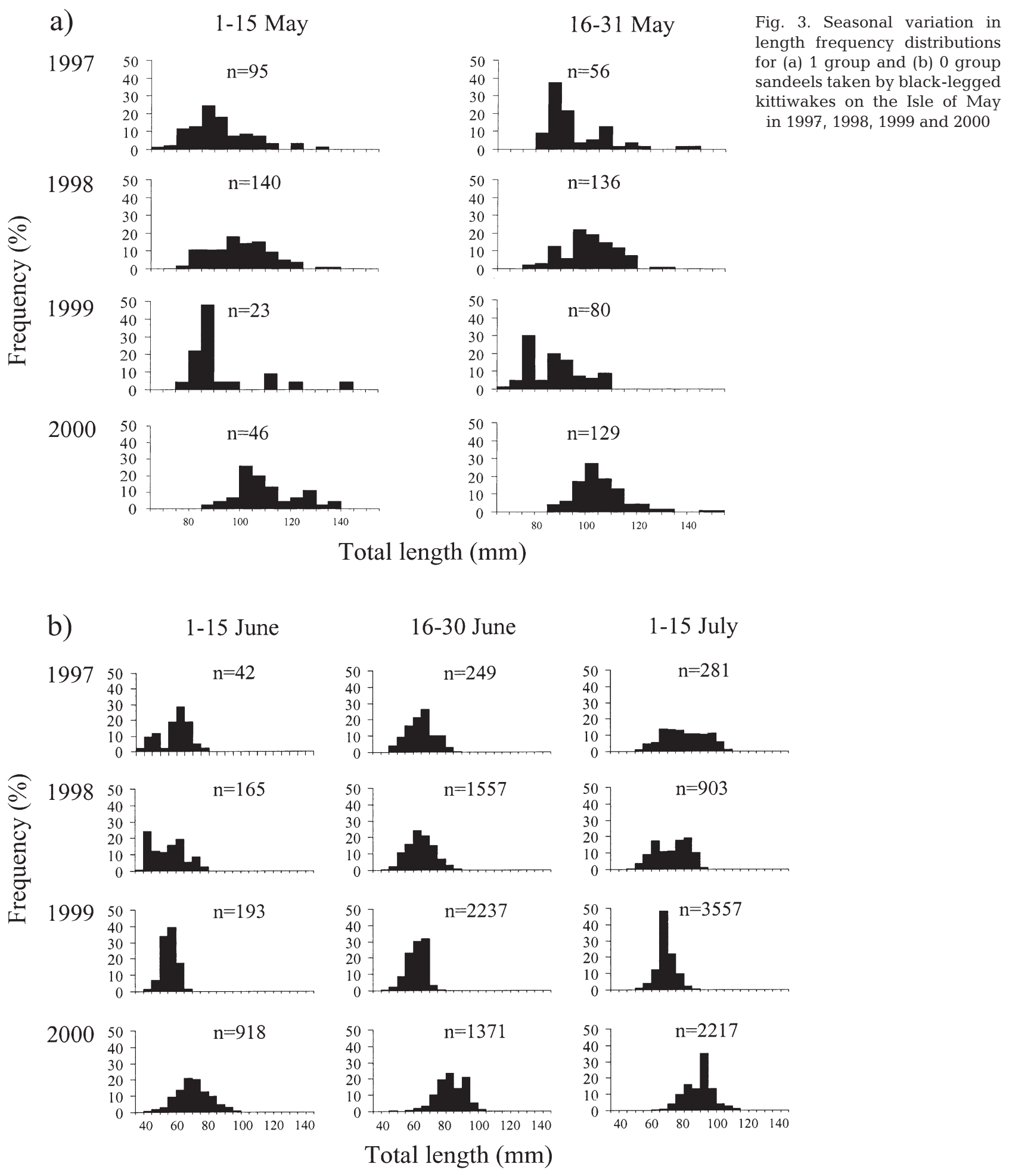

Size frequency distributions of 0 group and 1 group sandeels taken by kittiwakes differed markedly among years, fish in both age classes being consistently larger in 2000 than in the other 3 years (Fig. 3). The source of this variation was explored in more detail by comparing re- lations between fish length and date. Among 1 group sandeels there was no evidence of any systematic within-season change in TL except in 1997, when there was a $33 \%$ increase in average length between early May and mid-June (Fig. 4a). Fish in 2000 were consis- 


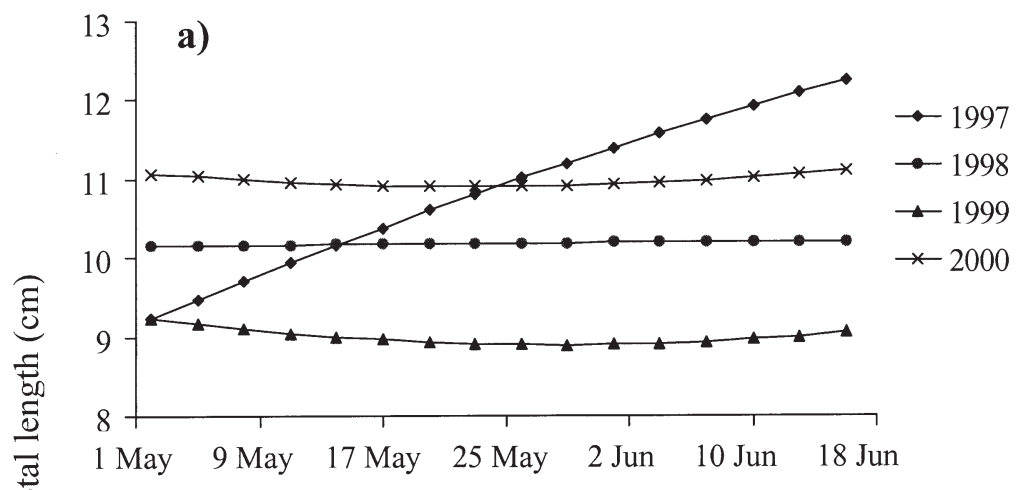

failure in 1998 (0.02 young in each active nest, $\mathrm{n}=683$ ), poor success in 1999 (0.20 young in each active nest, $\mathrm{n}=616$ ), low success in 1997 ( 0.40 young in each active nest, $\mathrm{n}=822)$ and fairly high success in 2000 (0.97 young in each active nest, $\mathrm{n}=545)$. In 1997, 1998 and 1999 there was a sharp increase in failure rate in the latter half of June with the effect being particularly marked in 1998 (Fig. 5). In 2000, the few losses were mainly associated with a severe storm in the middle of June.

\section{DISCUSSION}

Previous studies in the North Sea have shown a link between kittiwake breeding success and both 0 group and 1 group sandeels (Harris \& Wanless 1990, 1997, Hamer et al. 1992, Wanless \& Harris 1992, Monaghan 1996, Furness 1999a,b, Rindorf et al. 2000). Our investigation of kittiwake diet indicates that both these age classes are important and, for the first time, documents a well-defined seasonal change in diet from planktonic crustacea in early spring, to 1+ group sandeels in April and May, to 0 group sandeels in June and July (Table 1 \& Fig. 2). This pattern accords well with predictions of how age-specific, seasonal changes in sandeel behaviour would affect a surface-feeding predator such as the kittiwake. As with other sandeel species, Ammodytes marinus spends much of its

1999, while 1 group in 1997 switched from being joint smallest relative to the other years at the start of the sampling period to being, on average, larger by the end (Wald statistics for inter-year comparisons for selected dates: 1 May $\chi^{2}{ }_{3}=21.6 ; 23$ May $\chi^{2}{ }_{3}=181.9$; 15 June $\chi_{3}^{2}=187.2$; all $\mathrm{p}<0.001$ ). Among 0 group fish inter-annual differences in mean TL were already apparent in early June when this age class appeared in the kittiwake diet, with fish in 2000 being larger than those in 1997, 1998 and 1999 (Fig. 4b). These inter-annual differences became more pronounced as the season progressed (Wald statistics for inter-year comparisons for selected dates: 1 June $\chi^{2}{ }_{3}=214.3$; 15 June $\chi^{2}{ }_{3}=1513.0 ; 1$ July $\chi^{2}{ }_{3}=1315.0$; all $\mathrm{p}<0.001$ ). Hence by early July there was a $35 \%$ differential between values in the 2 extreme years (1999 and 2000).

\section{Reproductive output}

During the study there were marked among-year differences in kittiwake productivity, with the colony experiencing an almost complete breeding

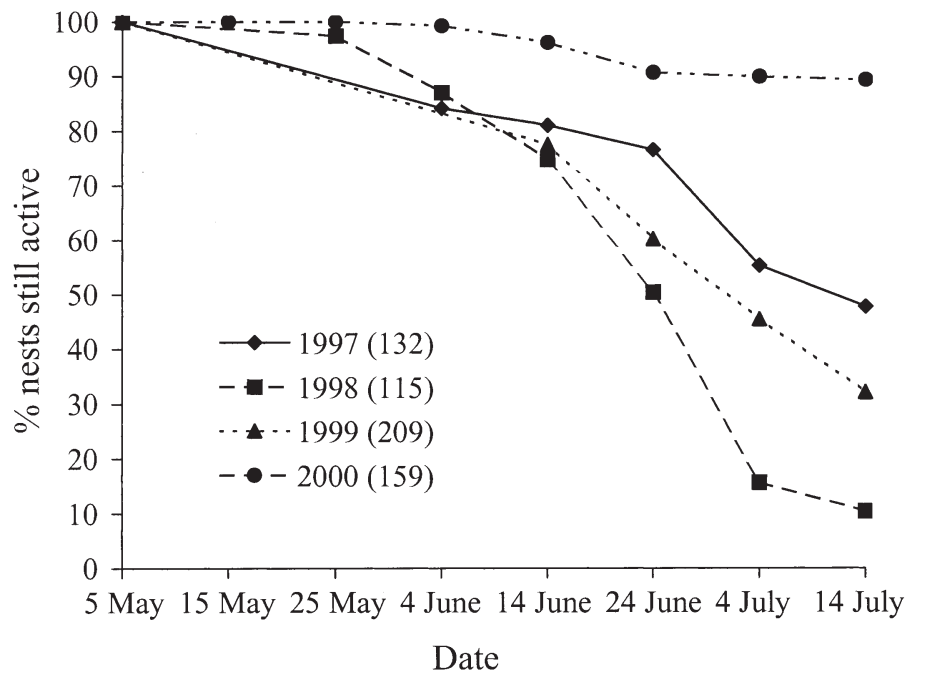

Fig. 5. Seasonal trends in breeding failures of black-legged kittiwakes on the Isle of May between 1997 and 2000. The number of nests followed each year is given in brackets 
Table 1. Frequency (\%) of occurrence of different prey items in regurgitates from kittiwakes on the Isle of May, between March and July 1997 to 2000

\begin{tabular}{|c|c|c|c|c|c|c|}
\hline & & ch-April & May & June & July & Total \\
\hline 1997 & Total no. of regurgitates & 2 & 48 & 46 & 20 & 116 \\
\hline \multirow[t]{7}{*}{$\%$ with } & Sandeel (all) & 0 & 92 & 96 & 100 & 93 \\
\hline & Sandeel (0 group) & 0 & 6 & 65 & 90 & 44 \\
\hline & Sandeel (1+ group) & 0 & 85 & 52 & 30 & 61 \\
\hline & Clupeidae & 0 & 4 & 15 & 10 & 10 \\
\hline & Gadidae & 0 & 6 & 7 & 5 & 6 \\
\hline & Planktonic crustacea & 100 & 17 & 2 & 0 & 10 \\
\hline & Sewage & 0 & 0 & 0 & 5 & 1 \\
\hline 1998 & Total no. of regurgitates & 22 & 62 & 110 & 23 & 217 \\
\hline \multirow{8}{*}{$\%$ with } & Sandeel (all) & 86 & 84 & 87 & 91 & 87 \\
\hline & Sandeel (0 group) & 0 & 0 & 59 & 87 & 39 \\
\hline & Sandeel (1+ group) & 86 & 84 & 50 & 4 & 59 \\
\hline & Clupeidae & 14 & 10 & 16 & 17 & 14 \\
\hline & Gadidae & 0 & 5 & 3 & 0 & 3 \\
\hline & Planktonic crustacea & 55 & 0 & 0 & 0 & 6 \\
\hline & Polychaetae & 14 & 2 & 2 & 0 & 3 \\
\hline & Sewage & 0 & 7 & 5 & 4 & 5 \\
\hline 1999 & Total no. of regurgitates & 5 & 58 & 79 & 39 & 181 \\
\hline \multirow{6}{*}{$\%$ with } & Sandeel (all) & 20 & 90 & 86 & 97 & 88 \\
\hline & Sandeel (0 group) & 0 & 17 & 71 & 92 & 56 \\
\hline & Sandeel (1+group) & 20 & 86 & 28 & 13 & 43 \\
\hline & Clupeidae & 20 & 12 & 32 & 10 & 20 \\
\hline & Gadidae & 0 & 7 & 15 & 5 & 10 \\
\hline & Planktonic crustacea & 60 & 9 & 10 & 0 & 9 \\
\hline 2000 & Total no. of regurgitates & 6 & 43 & 96 & 26 & 171 \\
\hline \multirow[t]{6}{*}{$\%$ with } & Sandeel (all) & 17 & 95 & 96 & 100 & 94 \\
\hline & Sandeel (0 group) & 0 & 14 & 81 & 100 & 64 \\
\hline & Sandeel (1+ group) & 17 & 91 & 28 & 15 & 42 \\
\hline & Clupeidae & 0 & 10 & 21 & 8 & 15 \\
\hline & Gadidae & 0 & 5 & 9 & 0 & 6 \\
\hline & Planktonic crustacea & 100 & 5 & 1 & 0 & 5 \\
\hline
\end{tabular}

A. marinus has a planktonic larval stage that lasts for 2 to 3 months, and most larvae metamorphose into juveniles and are actively schooling by late May or early June (Wright \& Bailey 1996). Consequently, the progressive increase in the importance of 0 group sandeels in kittiwake diet during June is consistent with the timing of metamorphosis of larval fish and hence the appearance of shoals of 0 group sandeels near the surface.

While the data on kittiwake diet composition were indicative of rather little variation between years, information on kittiwake productivity indicated otherwise, with output varying dramatically during the study. All the evidence suggests that food shortage rather than other factors, e.g. predation or disease, was responsible for the poor breeding success. Kittiwakes were apparently unable to compensate for changes in sandeel abundance by switching to alternative prey even though food samples from diving seabirds, e.g. common guillemots Uria aalge and Atlantic puffins, indicated that small clupeids were potentially available in mid-water (unpubl. data).

There was, however, evidence that temporal differences in sandeel life history events were well reflected in both kittiwake diet and breeding. Thus, the most successful year (2000) was characterised by the earliest appearance of 0 group

life buried in sandy substrata (Macer 1966, Reay 1970). Observations on the species' availability to fisheries (Macer 1966) and occurrence in sediments (Cameron 1958) suggest that, with the exception of the spawning period in December and January (Gauld \& Hutcheon 1990), sandeels rarely emerge from the sediment between September and March. In line with this we found by far the lowest proportion of sandeels in kittiwake diet samples in March and April. Even during the early summer when sandeels are active in the water column, fish emerge only during daylight hours in order to feed, and the overall duration of this active phase depends on the rate at which lipid reserves are laid down (Winslade 1974). Evidence from dredging (Wright \& Bailey 1993) and commercial bottom trawls (Reeves 1994) suggests that 1 group and older sandeels spend a decreasing time in the water column from July onwards, and these age classes of sandeels were almost completely absent from kittiwake samples collected at this time. The appearance of 0 group sandeels in kittiwake samples was also consistent with the activity patterns of this age class. Thus, in the North Sea sandeels and the least successful year (1998) had the latest appearance date. It was possible that this effect was further exacerbated by the age structure of the sandeel population in the first half of the season, with poor kittiwake breeding years being those with higher proportions of sandeels $>1 \mathrm{yr}$ old present in the diet. There is some evidence that older sandeels return to the substratum earlier in the year than younger ones (Wright \& Bailey 1993, Reeves 1994), thus decreasing their availability to predators, particularly surface feeders. In line with this, in all the years except 2000, the probability of a kittiwake regurgitating decreased markedly in late May to early June during the transition from $1+$ to 0 group sandeels. This suggested that birds were finding it harder to find food at this time, particularly in 1998 and 1999 when the proportion of sandeels $>1$ yr old in the diet was higher (Fig. 2). In contrast, in 2000, the regurgitation rate declined later, was less marked and was of shorter duration. These results are consistent with those of Rindorf et al. (2000), who also concluded that the success of seabirds, including kittiwakes, in this area was influenced by the 
timing of sandeel life history events. Their analysis was restricted to the availability of $1+$ group sandeels but they speculated that poor breeding success was associated with an early onset of burying behaviour of $1+$ group fish coupled with a late arrival of 0 group sandeels in the seabirds' feeding areas.

The timing of the shift from $1+$ group to 0 group sandeels made it inevitable that 0 group was the predominant age class used to provision chicks during most of the nestling period. This reliance has important energetic implications because young fish tend to exhibit greater inter-annual variability in growth than older age classes (Cameron 1958, Wright 1996, Wright \& Bailey 1996). In the 3 years of poor or low kittiwake breeding success, most of the pairs failed towards the end of June when 0 group accounted for $>95 \%$ of the sandeels taken. These failures occurred approximately midway through the kittiwake chick rearing period when annual differences in 0 group size had become apparent. The link between poor breeding success and small prey size can potentially be explained in terms of the size-dependent variation in energy density of sandeels, which increases as a power function of length (Hislop et al. 1991). Comparing the percentage of nests that were still active at the start of July with the energy value of 0 group sandeel in the diet at this time suggests a positive correlation (Fig. 6), although clearly, more data are needed to establish formal statistical significance. While it is likely that the observed seasonal increase in sandeel size reflects the growth of 0 group, we cannot exclude the possibility that it reflects the movement of fish into the kittiwakes' foraging area, as was found in Shetland (Wright 1996), or a shift in the foraging area used by the birds. Further work is required to investigate fine-scale spatial and temporal changes in the distributions of both predators and prey.

Our study of kittiwake diet and breeding success included 3 seasons $(1997,1998,1999)$ in which the indus-

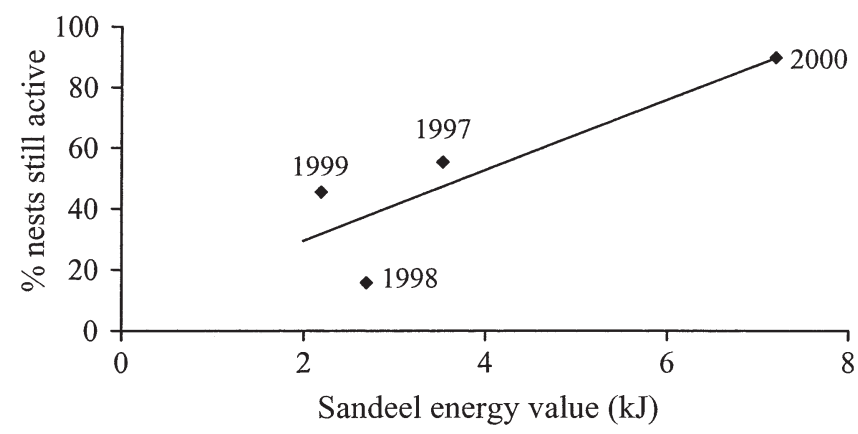

Fig. 6. Percentage of nests still active at the start of July in relation to the concurrent energy values of 0 group sandeels in the diet of black-legged kittiwakes on the Isle of May between 1997 and 2000 trial sandeel fishery on the Wee Bankie was operating and 1 (2000) in which the area was closed. This closure was in response to concern about the series of breeding failures at kittiwake colonies along the east coast of Britain in recent years (ICES 2000). At face value the return to levels of breeding success typical of the pre-fishery period, as recorded on the Isle of May and other east coast colonies in 2000 (Mavor et al. pers. comm., and the present study; cf. Harris \& Wanless 1997), may be attributed to the closure of the fishery having an immediate and positive effect on kittiwake productivity. However, our dietary data from Isle of May kittiwakes indicate that 2000 was also characterised by the early appearance and rapid growth of 0 group sandeels. Thus, we cannot exclude the possibility that the observed improvement in kittiwake breeding success was due, at least in part, to environmental factors that affected the growth and life histories of sandeels. Hence, differences in the availability of suitably sized sandeels could have been the principal reason for inter-annual differences in breeding success, rather than any direct effects of fishing. In a previous study of seabirds and sandeels at Shetland, breeding success of kittiwakes was found to be influenced by 3 components of prey availability: stock size, the size of 0 group sandeels and the time when they became available during the chick rearing period (Wright 1996). The lowest breeding success coincided with the poorest year of recruitment in 1990. However, the effect of a small year class was exacerbated because most of the 0 group in 1990 appeared in Shetland waters several weeks later than usual and their growth rate was very low in that year (Wright \& Bailey 1996). Our results for a colony in the northwestern North Sea in an area where, unlike Shetland, alternative prey are potentially available (Daan et al. 1990) further emphasise the tight linkage between kittiwake productivity and sandeel recruitment. However, our study also highlights the importance of 1+ group sandeels to kittiwakes early in the season, before and during incubation. Clearly the factors that are important at this time now need to be investigated.

Acknowledgements. This study was carried out with financial support from the European Commission Study Contract 95/C76/15 'Effects of Large-Scale Industrial Fisheries on NonTarget Species' and used data collected by the Centre for Ecology and Hydrology (formerly the Institute of Terrestrial Ecology) under a contract with the Joint Nature Conservation Committee (JNCC). We are grateful to JNCC for additional financial assistance in 1999. We thank the many people who helped in the field, particularly Bernadette Clarke, David Hammond and Robin Cox, who collected diet samples in 1997, 1999 and 2000, respectively; Iain Gibb and Fiona Kenedy for help ageing otoliths; and Francis Daunt, Robert Kempton, Mark Tasker, Kate Thompson and 3 anonymous referees for helpful comments on an earlier version of the paper. 
Appendix 1. Year-specific and age class-specific calibration equations used to back-calculate total sandeel lengths (TL, in mm) from maximum otolith diameters (MOD, in $\mathrm{mm}$ )

\begin{tabular}{|c|c|c|c|c|c|c|c|c|}
\hline Year & $\mathrm{n}$ & $\begin{array}{l}0 \text { group } \\
\text { Equation }\end{array}$ & $r^{2}$ & $\mathrm{p}$ & $\mathrm{n}$ & $\begin{array}{l}1+\text { group } \\
\text { Equation }\end{array}$ & $\mathrm{r}^{2}$ & $\mathrm{p}$ \\
\hline 1997 & 179 & $\mathrm{TL}=66.38 \mathrm{MOD}+0.39$ & 84.8 & $<0.001$ & 83 & $\mathrm{TL}=59.51 \mathrm{MOD}-1.58$ & 61.9 & $<0.001$ \\
\hline 1998 & 229 & $\mathrm{TL}=46.82 \mathrm{MOD}+21.32$ & 93.2 & $<0.001$ & 243 & $\mathrm{TL}=67.69 \mathrm{MOD}-15.16$ & 71.8 & $<0.001$ \\
\hline 1999 & 225 & $\mathrm{TL}=49.59 \mathrm{MOD}+17.12$ & 89.1 & $<0.001$ & 81 & $\mathrm{TL}=71.89 \mathrm{MOD}-42.75$ & 97.0 & $<0.001$ \\
\hline 2000 & 430 & $\mathrm{TL}=58.70 \mathrm{MOD}+18.76$ & 81.2 & $<0.001$ & 312 & $\mathrm{TL}=64.59 \mathrm{MOD}-14.80$ & 83.8 & $<0.001$ \\
\hline
\end{tabular}

\section{LITERATURE CITED}

Bailey RS (1991) The interaction between sandeels and seabirds - a case history at Shetland. ICES (International Council for the Exploration of the Sea), CM 1991/L:41

Cameron J (1958) Studies on the Ammodytidae of Isle of Man waters. PhD thesis, University of Liverpool

Daan N, Bromley PJ, Hislop JRG, Neilsen NA (1990) Ecology of the North Sea fish. Neth J Sea Res 26:342-386

Furness RW (1990) A preliminary assessment of the quantities of Shetland sandeel taken by seabirds, seals, predatory fish and the industrial fishery in 1981-1983. Ibis 132:205-217

Furness RW (1999a) Does harvesting a million metric tons of sand lance per year from the North Sea threaten seabird populations? Ecosystem approaches for fisheries management. Alaska Sea Grant College Report 99-01, University of Alaska, Fairbanks, p 407-424

Furness RW (1999b) Towards defining a sandeel biomass limit for successful breeding by seabirds. In: Wright PJ, Kennedy FM (eds) Sandeel biology and its implications to management. Fisheries Research Services Report No 12/99, Aberdeen, p 22-27

Furness RW, Tasker ML (2000) Seabird-fishery interactions: quantifying the sensitivity of seabirds to reductions in sandeel abundance, and identification of key areas for sensitive seabirds in the North Sea. Mar Ecol Prog Ser 202: 253-264

Gauld JA, Hutcheon JR (1990) Spawning and fecundity in the lesser sandeel, Ammodytes marinus Raitt, in the northwestern North Sea. J Fish Biol 36:611-613

Gislason H, Kirkegaard E (1998) Is the industrial fishery in the North Sea sustainable? In: Symes D (ed) Northern waters: management issues and practice. Fishing News Books, Blackwell, Oxford, p 195-207

Hamer KC, Furness RW, Caldow RWG (1991) The effects of changes in food availability on the breeding ecology of Great Skuas Catharacta skua in Shetland. J Zool 223: 175-188

Hamer KC, Monaghan P, Uttley JD, Walton P, Burns MD (1992) The influence of food supply on the breeding ecology of Kittiwakes Rissa tridactyla in Shetland. Ibis 135: 255-263

Härkönen T (1986) Otoliths: guide to the otoliths of the bony fishes on the northeast Atlantic. Danbiu ApS, Hellerup

Harris MP, Riddiford NJ (1989) The food of some young seabirds on Fair Isle in 1986-88. Scott Birds 15:119-125

Harris MP, Wanless S (1990) Breeding success of British kittiwakes Rissa tridactyla in 1986-88: evidence for changing conditions in the northern North Sea. J Appl Ecol 27: 172-187

Harris MP, Wanless S (1991) The importance of the lesser sandeel Ammodytes marinus in the diet of the shag Phalacrocorax aristotelis. Ornis Scand 22:375-882

Editorial responsibility: Otto Kinne (Editor),

Oldendorf/Luhe, Germany
Harris MP, Wanless S (1997) Breeding success, diet, and brood neglect in the kittiwake (Rissa tridactyla) over an 11-year period. ICES J Mar Sci 54:615-623

Heubeck M, Ellis PM (1986) Shetland seabirds 1985. BTO News 143

Hislop JRG, Harris MP, Smith JGM (1991) Variation in the calorific value and total energy content of the lesser sandeel (Ammodytes marinus) and other fish preyed on by seabirds. J Zool 224:501-517

ICES (1995) Report of the ICES workshop on sandeel otolith analysis: review of sandeel biology. ICES CM 1995/G:4

ICES (2000) Sandeel/seabird interactions. Report of the ICES Advisory Committee of the Marine Environment 1999. ICES Coop Res Rep 239

ICES (2001) Report of the ICES Advisory Committee on the Fisheries Management 2000. ICES Coop Res Rep 242

Macer CT (1966) Sandeels (Ammodytidae) in the southwestern North Sea; their biology and fishery. MAFF Fish Invest 2 24:1-51

Monaghan P (1992) Seabirds and sandeels: the conflict between exploitation and conservation in the northern North Sea. Biodivers Conserv 1:98-111

Monaghan P (1996) Relevance of the behaviour of seabirds to the conservation of marine environments. Oikos 77:227-237

Monaghan P, Uttley JD, Okill D (1989) Terns and sandeels: seabirds as indicators of change in marine fish populations. J Fish Biol 35(Suppl A):339-340

Reay PJ (1970) Synopsis of biological data on North Atlantic sandeels of the genus Ammodytes. FAO Fish Synop 82

Reeves SA (1994) Seasonal and annual variation in catchability of sandeels at Shetland. ICES CM 1994/D:19

Rindorf A, Wanless S, Harris MP (2000) Effects of changes in sandeel availability on the reproductive output of seabirds. Mar Ecol Prog Ser 202:241-252

Wanless S, Harris MP (1992) Activity budgets, diet and breeding success of Kittiwakes Rissa tridactyla on the Isle of May. Bird Study 39:145-154

Watt J, Pierce GJ, Boyle PR (1997) Guide to the identification of North Sea fish using premaxillae and vertebrae. ICES Coop Res Rep 220

Winslade P (1974) Behavioural studies on the lesser sandeel, Ammodytes marinus. Part 2. The effect of light intensity on activity. J Fish Biol 6:577-586

Wright PJ (1996) Is there a conflict between sandeel fisheries and seabirds? A case study at Shetland. In: Greenstreet SPR, Tasker ML (ed) Aquatic predators and their prey. Fishing News Books, Blackwell Science, Oxford, p 154-165

Wright PJ, Bailey MC (1993) Biology of sandeels in the vicinity of seabird colonies at Shetland. Fisheries Research Report 15/93. SOAFD Marine Laboratory, Aberdeen

Wright PJ, Bailey MC (1996) Time of hatching in Ammodytes marinus from Shetland waters and its significance to early growth and survivorship. Mar Biol 126:143-152

Submitted: December 7, 2000; Accepted: March 27, 2001

Proofs received from author(s): September 28, 2001 